\title{
Implementing Decentralized Local Governance: A Treacherous Road with Potholes, Detours and Road Closures ${ }^{1}$
}

By Anwar Shah² and Theresa Thompson, World Bank

\begin{abstract}
World Bank Policy Research Working Paper 3353, June 2004
The Policy Research Working Paper Series disseminates the findings of work in progress to encourage the exchange of ideas about development issues. An objective of the series is to get the findings out quickly, even if the presentations are less than fully polished. The papers carry the names of the authors and should be cited accordingly. The findings, interpretations, and conclusions expressed in this paper are entirely those of the authors. They do not necessarily represent the view of the World Bank, its Executive Directors, or the countries they represent. Policy Research Working Papers are available online at http:/lecon.worldbank.org.
\end{abstract}

\footnotetext{
${ }^{1}$ This is the revised version of the paper presented at the conference "Can Decentralization Help Rebuild Indonesia?" sponsored by the Andrew Young School of Policy Studies, Georgia State University, Atlanta, Georgia, May 1-3, 2002. The authors are grateful to Jorge Martinez for suggesting this topic and to Ryaas Rasyid, Pak Machfud, Bert Hofman, Kai Kaiser, and Matthew Andrews for comments.

${ }^{2}$ Anwar Shah is the Program Leader for Public Sector Governance and Theresa Thompson is a consultant, both at the World Bank Institute.
} 


\begin{abstract}
Summary of Results:
During the past two decades, a silent revolution in public sector governance has swept across the globe aiming to move decision making for local public services closer to the people. The countries embracing and adapting to this silent revolution have had diverse motives and followed even more diverse approaches. This paper attempts to present a stylized view of the motivations and approaches used to strengthen local governance.

The quest for the right balance, i.e. appropriate division of powers among different levels of government, is not always the primary reason for decentralizing. There is evidence that the decentralization decision may have more to do with short-term political considerations than the long-run benefits of decentralization. To take stock of progress worldwide, we take a comparative look at developments in political, fiscal and administrative decentralization for a selected group of countries.

Most of the decentralization literature deals with normative issues regarding the assignment of responsibilities among different levels of government and the design of fiscal transfers. The process of decentralization has not received the attention it deserves as the best laid plans can fail due to implementation difficulties. We revisit major controversies regarding preferred approaches to obtaining a successful outcome. Key approaches examined are big push versus small steps; bottom up vs. top down; and uniform vs. asymmetric decentralization.

Finally, Indonesia's 1999 "big bang" decentralization program is evaluated. The program should be commended for its achievements over a short period of time, however incentives are lacking for local governments to be accountable and responsive to their residents.
\end{abstract}




\section{Table of Contents}

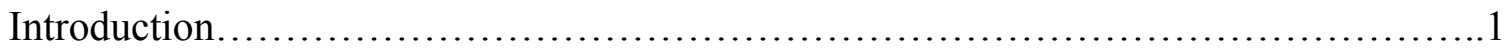

1. Decentralization: Some Basic Concepts......................................

2. Why countries are decentralizing? Not Always for the Right Balance.................3

3. What are they decentralizing and for what purposes?.............................6

Political decentralization..................................................

Administrative decentralization..............................................

Fiscal decentralization.......................................................

(a) Revenue autonomy and adequacy .............................. 8

(b) Expenditure responsibility and autonomy.........................11

(c) Fiscal transfers: A mixed grab bag..............................14

(d) Borrowing privileges.......................................... 17

4. How do we get there? Revisiting major controversies on the process of decentralization.......................................................... 18

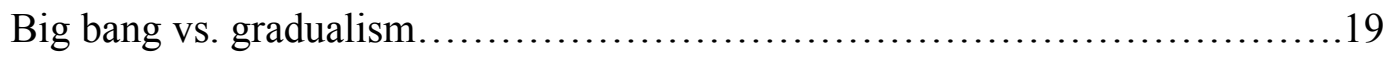

Are there any true big bang reformers? ................................... 20

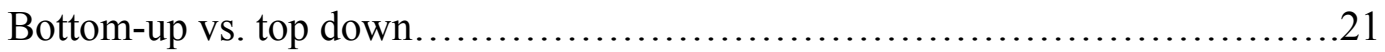

Uniform vs. asymmetric decentralization.................................22

5. Will decentralization be sustained? ..............................................

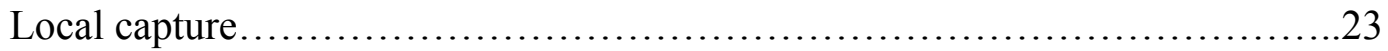

6. Lessons for the Future of Decentralization in Indonesia............................24

Missing links in the Indonesian Decentralization Program.......................25

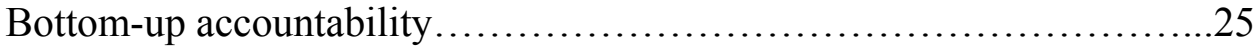

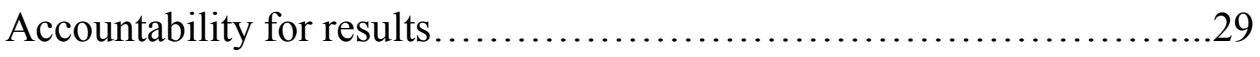

Bureaucratic culture and incentives..................................... 31

Results Oriented Management and Evaluation (ROME) Chain:.........................32

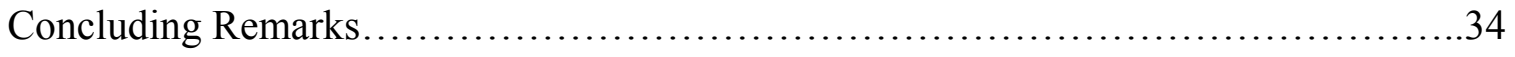

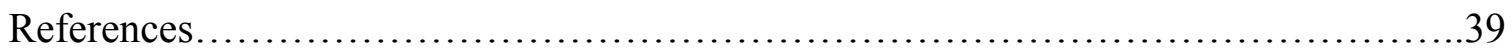




\section{Tables:}

Table 1. Motivations for Decentralization....................................... 3

Table 2: Central Involvement in Local Functions Remains Extensive...................13

Table 3: Ensuring Consistency of Grant Design to Achieve Grantor's Objectives.........15

\section{Boxes:}

Box 1: The New Fiscal Equalization Program in Indonesia..........................26

Box 2: An Example of a Performance Oriented Grant: Education grant to set minimum standards while encouraging competition and innovation...................... 30

Box 3: Making the Dog Wag Its Tail: Accountability for Results.....................34

\section{Appendix:}

Appendix Table 1: Political Decentralization.................................. 35

Appendix Table 2: Administrative Decentralization................................36

Appendix Table 3: Fiscal Decentralization.......................................... 


\section{Introduction}

During the past two decades, a silent revolution in public sector governance has swept across the globe ${ }^{3}$. This revolution aims to move decision making for local public services closer to the people. The interest in this new paradigm of public governance has further been heightened by the information revolution and globalization of economic activity, which tends to weaken the central government at the expense of supranational regimes and local governments.

The countries embracing and adapting to this silent revolution have had diverse motives and followed even more diverse approaches. This paper attempts to present a stylized view of the motivations and the approaches and processes used to strengthen localization. In doing so, it attempts to draw lessons of some general interest on the process and substance of decentralization.

The paper is organized as follows. Section 1 introduces the reader to basic concepts in decentralization. Section 2 is concerned with the motivations for decentralization. Section 3 presents a worldwide overview of decentralization efforts. Section 4 is concerned with the processes of decentralization and examines sequencing issues. Section 5 deals with sustainability and local capture issues. Section 6 draws lessons for the future of the decentralization process in Indonesia that began in 1999.

\section{Decentralization: Some Basic Concepts}

A review of basic concepts commonly used in the decentralization literature is presented below so as to facilitate communications in subsequent sections.

\footnotetext{
${ }^{3}$ This silent revolution has led to break-up of existing countries and moves towards democratization and confederal or federal forms of governance. The total number of countries has risen from 140 in 1975 to 192 in 2001 and of these 25\% were democracies in 1975 compared to $60 \%$ in 2001. In 2001, there are 24 federal countries with $25.4 \%$ of the world population with another 20 decentralized unitary countries with some federal features having 35\% of world population (see also Watts, 1999). The World Bank has had programs in support of decentralization in 74 countries during 1986-2001.
} 
- The subsidiarity principle states that public service responsibilities must be exercised by the lowest level of government unless a convincing case can be made for higher level assignment.

- A unitary country has a single or multi-tiered government in which effective control of government functions rests with the central government.

- A federal form of government has a multilayered structure with decision making shared by all levels of government.

- In a confederal system of government, the central government serves as the agent of member units, usually without independent taxing and spending powers. The European Union is an important example of a confederal form of government. Switzerland has a confederal constitution but is considered a federal country in practice.

- Devolution means empowering people politically.

- Localization means decentralization of decision making to the local level. It is pursued through political, administrative and fiscal decentralization.

- Political or democratic decentralization implies directly elected local governments thereby making elected officials accountable to citizens.

- Administrative decentralization empowers these governments to hire and fire local staff (thereby making local officials accountable to elected officials) without any reference to higher-level governments.

- Fiscal decentralization ensures that all elected officials weigh carefully the joys of spending someone else's money as well as the pain associated with raising revenues from the electorate and facing the possibility of being voted out.

- Administrative deconcentration, where decision making is shifted to regional and local offices of the central government, would not be consistent with administrative decentralization.

- Similarly administrative delegation where local governments undertake activities on behalf of the higher-level governments falls short of administrative decentralization. 


\section{Why Are Countries Decentralizing? Not Always for the Right Balance}

The reasons for rethinking fiscal arrangements are manifold and the importance of each factor is country specific. Table 1 presents prime motivations in recent decentralization moves. The table shows that the quest for right balance, i.e. appropriate division of powers among different levels of government, is not always the primary reason for implementing decentralization. Instead various political and economic events have often triggered such an interest.

\section{Table 1. Motivations for Decentralization}

\begin{tabular}{|l|l|}
\hline Motivation & Countries and/or regions \\
\hline Political and economic transformation & Central and Eastern Europe, Russia \\
\hline Political crisis due to ethnic conflict & $\begin{array}{l}\text { Bosnia-Herzegovina, Ethiopia, Yugoslavia, Nigeria, Sri } \\
\text { Lanka, South Africa, Philippines }\end{array}$ \\
\hline Political crisis due to regional conflicts & $\begin{array}{l}\text { Indonesia, Madagascar, Mali, Senegal, Uganda, } \\
\text { Mexico, Philippines }\end{array}$ \\
\hline Enhancing participation & $\begin{array}{l}\text { Argentina, Brazil, Bolivia, Colombia, India, Pakistan, } \\
\text { Philippines }\end{array}$ \\
\hline Interest in EU Accession & Czech Republic, Slovakia, Hungary, Poland \\
\hline Political maneuvering & Peru, Pakistan \\
\hline Fiscal crisis & Russia, Indonesia, Pakistan \\
\hline Improving service delivery & Chile, Uganda, Cote D'Ivoire \\
\hline To centralize & China, Turkey, European Union \\
\hline Shifting deficits downwards & Eastern and Central Europe, Russia \\
\hline Shifting responsibility for unpopular \\
adjustment programs & Africa \\
\hline Prevent return to autocracy & Latin America \\
\hline Preservation of Communist rule & China \\
\hline Globalization and information & Most countries \\
\hline
\end{tabular}


Table 1 shows that on the domestic front, political considerations have been the major catalyst in initiating a process of decentralization. These considerations had broader goals of political and economic transformation and aspirations for European Union membership in former centrally planned economies. In most other countries, the agenda for reform was driven by ethnic and regional conflicts and fiscal crisis. Interestingly enough, in some countries, such as Indonesia and Pakistan, decentralization processes that had been stuck in the mud for a long time got a big boost by political and fiscal crises. In Peru and Pakistan, recent decentralization moves had their origins in attempts by regimes in power to sideline or weaken potential opposition.

While the political process of decentralization is important, it is an issue that has not yet been explored in the literature as highlighted by the following quotes:

\begin{abstract}
What is efficient—or even optimal—from an economic viewpoint might not always be sustainable politically. I believe one of the greatest challenges ahead of us as formal scholars of federalism is to synthesize the two branches of the literature, to consider how policy efficiency and political feasibility are related...Questions of when to decentralize, how, and to whom - questions regularly raised by the policy literature - might not be best answered by examining policy efficiency, but instead ought to be informed by work on political feasibility. (Jenna Bednar, APSA-CP Newsletter, Winter 2000)

How do inter-governmental politics, party structures, political career patterns, clientelistic networks, and interest group pressures shape the causes and consequences of decentralization? Answers to this question would not only shed new light on the conditions under which decentralization may be expected to yield its theorized benefits, but also help to advance ongoing but increasingly sterile debates about the quality of democracy in the region [Latin America]. (Remmer and Wibbels APSA-CP Newsletter, Winter 2000)
\end{abstract}

Political scientists see federalism as a way to promote political stability in fractured societies (see Susan Rose-Ackerman, 2000). This seems to have been part of the reason for decentralization in Uganda where there is a geographical divide among ethnic groups.

There is some evidence to show that the decision to decentralize may have more to do with short-term political considerations of politicians rather than being based on the perceived benefits of decentralization in the long run. Eaton (2001) suggests the following possible political motivations for decentralization: 
i. Decentralization might be a voluntary choice of politicians-it can increase political stability and economic growth in a way that compensates politicians for any loss of power they may experience in the short run (see also Manor, 1999).

ii. Decentralization may result from political pressures exerted by sub-national politicians. If sub-national politicians can influence the political careers of their representatives in the national assembly, these legislators may be coerced into supporting decentralization (according to Willis et al, 1999). In Brazil, the return to democracy in the 1980s set the stage for fiscal decentralization when governors regained political influence.

iii. Decentralization may reflect short-term gains for politicians, since politicians usually discount future gains heavily. When government is divided, the party in control of the legislature may promote decentralization as a way to constrain the executive branch. Experiences of Argentina and the Philippines suggest that political struggles over the control of revenues and expenditures may have less to do with substantive debates over development strategy than with short-term and highly dynamic political calculations.

External influences through globalization and the information revolution are also having profound influences on the division of power within nations. The information revolution has weakened the ability of governments to control information flows. With globalization, it is increasingly becoming apparent that nation states are too small to tackle large things in life and too large to address small things. More simply, nation states are fast loosing control of some of their areas of traditional control and regulation, such as regulation of external trade, telecommunications, and financial transactions. National governments are experiencing diminished control in their ability to control the flow of goods and services, ideas and cultural products. These difficulties are paving the way for the emergence of specialized institutions of global governance such as the World Trade Organization, Global Environmental Facility, and many more to follow, especially institutions to regulate information technology, satellite communications, and international financial transactions. Even development finance institutions are assuming an increasingly powerful role in macroeconomic management. Thus nation states would 
be confederalizing in the coming years and relinquishing responsibilities in these areas to supranational institutions. This trend, however, contributes to a democracy deficit, as citizens do not have the possibility of direct input in vital decision making by supranational institutions.

The European Union's policies and principles regarding subsidiarity, fiscal harmonization and stabilization checks are also having demonstrable effects on developing and transition economies' (DTEs) policies.

\section{What Are They Decentralizing and For What Purposes?}

Moving decision-making closer to people requires that citizens have voice and exit options for local governance (political decentralization). In addition, local governments they elect should be allowed home rule in fiscal, regulatory and administrative matters (fiscal and administrative decentralization). All of these elements must be in place to ensure effective decision making at the local level. It is interesting to note that very few developing countries have adopted such a comprehensive approach to the decentralization of decision-making. To take stock of the progress of decentralization worldwide, we take a comparative look at key aspects of political, fiscal and administrative decentralization for a selected group of countries representing each region. From country experiences, we develop a stylized view of regional progress on decentralization (see Appendix Tables $1-3$ ).

The focus of this paper, by design, is on decentralization to municipal-local governments (such as municipalities, cities, and districts). This is because such a focus enables us to get a comparative perspective as to the extent decision making has been shifted to the people. This focus implies relative neglect of decentralization to the intermediate levels of government, as for example in Argentina and Mexico, where local governments are simply hand-maidens of the provinces/states and intermediate level governments have a large role in social services provision. 


\section{Political decentralization}

This represents the area of most intensive political interest and reform. Following the lead of Latin America, other regions have also carried out reforms in support of political decentralization. Among the countries selected for this study, the legal status of local government is recognized in most constitutions. Furthermore, local councils and their heads are typically elected through popular vote. The degree of popular participation and contestability of local government elections nevertheless remains low. Very few countries have provisions for popular recall of local officials. Provisions for the disbandment of local councils by higher-level governments have been enacted in most countries.

Overall, during the last two decades, there have been major gains in political decentralization worldwide with South America and Eastern Europe having completed

their agenda for reform in this area. Other regions have also shown progress but progress has been quite slow in Central America and non-existent in the Middle East and North Africa regions (see Appendix Table 1).

\section{Administrative Decentralization}

Effective administrative decentralization requires lack of any ex ante controls over the decision to hire, fire and set terms of employment of local staff. To improve tax collection or the delivery of local public services, local government should have the freedom to contract own taxing and spending responsibilities. Furthermore, local governments should have the authority to pass bylaws in their spheres of responsibility without having to obtain prior clearance from the higher level government.

In practice however, local governments in a large majority of countries do not have the authority to hire and fire senior local staff. Eastern European countries represent an important exception in this regard. The freedom to contract own responsibilities is typically available but this option in some cases, e.g. in the Philippines, is constrained to 
the expenditure side only. Regulatory authority for municipal services is usually available to local governments in most countries, although in Indonesia local government regulations have to be approved by the central government. Overall, there has been significant progress in administrative decentralization in developing countries in recent years (see Appendix Table 2). Such progress has been much slower in the area of local government autonomy for own civil service. In Pakistan, lack of such autonomy is considered the Achilles' heel of the devolution plan, as the provincially transferred civil servants have no personal stake in the success of the devolution. In Indonesia, the central government sets the minimum salaries for civil servants of sub-national governments.

\section{Fiscal Decentralization ${ }^{4}$}

Fiscal decentralization has three important components: (a) revenue autonomy and adequacy; (b) expenditure autonomy and; (c) borrowing privileges. The progress in these areas is reviewed in the following paragraphs (see also Appendix Table 3 ). ${ }^{5}$ Note that due to data limitations, the figures in these sections refer to sub-national levels (intermediate and local governments combined) rather than just local governments alone.

(a) Revenue Autonomy and Adequacy

The theoretical literature on fiscal federalism suggests that decentralization of taxing powers may not fully match the decentralization of expenditure and regulatory functions. This is largely because taxes on mobile bases and multi-stage sales taxes are better assigned to the national government in the interest of tax harmonization. However, in developing and transition economies (DTEs), centralization of taxing responsibilities is much more pronounced than would be based on economic considerations. In some countries, such as Mexico and Pakistan, the national government raises more than $90 \%$ of

\footnotetext{
${ }^{4}$ The section on Fiscal Decentralization draws on Shah, Anwar (2004). "Fiscal Decentralization in Developing and Transition Economies: Progress, Problems and the Promise" World Bank Policy Research Working Paper Series No. 3282. Washington, D.C.

${ }^{5}$ While the focus of this paper is on decentralization to the local level of government, the lack of available statistics on local government finance has resulted in our resort to the use of sub-national expenditures and revenues from the Government Finance Statistics database (IMF) in this section.
} 
consolidated public sector revenues. Revenue systems in developing and transition economies are typically characterized by a large and dominant central government role and heavy reliance on indirect taxes such VAT, excises, taxes on external trade and fuel taxes. Sub-national sales taxes are permitted in a number of countries including Brazil, India, Russia and Kyrgyz Republic. Sub-national level VAT is vogue only in Brazil (see Shah 2001, 1988, 1994 for practical difficulties with a sub-national VAT) but several Indian States have introduced multi-stage sales taxes.

Local governments have very limited access to own source revenues such as property taxes and user charges and even for these limited tax bases, they typically have autonomy only with respect to rate setting within limits. Even property related taxes, which are seen good sources of local revenue since the base is immobile, are under central control in some countries. In China and Indonesia, the central government levies taxes on land, property and housing, and in India state governments levy an urban property tax and taxes on property transactions. In Brazil, the rural property tax is in federal domain, in Nigeria state governments tax non-agricultural land and in Pakistan provincial governments are empowered to tax agricultural land. Private sector participation in collecting taxes and user fees on behalf of local governments is practiced in some countries. For example tax farming, whereby rights for revenue collection are auctioned, is practiced by local governments in Pakistan for collecting taxes and user fees. Currently, the proceeds of the land and buildings tax (Pajak Bumi dan Bangunan or PBB) and the land and buildings transfer tax (Bea Perolahan Hak atas Tanah dan Bangunan or BPHTB) in Indonesia are collected by the central government and shared with the local governments, thereby denying the local governments autonomy in this regard.

Sub-national own revenues constitute about $7.9 \%$ of GDP in transition economies ( $11 \%$ in Moldova, $10 \%$ in Belarus and $0.01 \%$ in Croatia) and 5.5\% of GDP in developing countries (8\% in Argentina, less than $1 \%$ in Bahrain and Mauritius and $0.1 \%$ in Dominican Republic) in $1999 .{ }^{6}$ In transition economies, on average sub-national

\footnotetext{
${ }^{6}$ Outliers to the averages for transition and developing countries are listed in parentheses.
} 
governments raise $18.4 \%$ of revenues of public sector revenues (52\% in China, and $3 \%$ in Albania) and in developing countries they raise slightly less - about $16.6 \%$ (39\% in Argentina and India and 0.8\% in Dominican Republic) in 1997. During the past two decades, transition economies have shown a decline in these revenues as tax collection was centralized whereas in developing countries, there has been a modest increase due to the small degree of tax decentralization. Sub-national revenues financed $55 \%$ of subnational operating expenditures in transition economies $(71 \%$ in Lithuania and $70 \%$ in Moldova, and $2 \%$ in Albania) and $40 \%$ of the same in developing countries (78\% in Argentina, 63\% in Costa Rica and 7\% in Peru and South Africa) in 1999. The rest of the financing comes from shared taxes, transfers and borrowing. Overall tax decentralization remains an unfinished agenda for DTEs.

The above discussion implicitly assumes that assignment of taxes entails control over tax base, tax rates and collection authority. This need not be the case and higher level governments may instead, in the interest of harmonization and minimizing collection and compliance costs, allow lower level governments to either levy a supplementary rate on their own base (tax base sharing) or agree to share the proceeds from specific taxes in a pre-determined way (shared taxes). Under such arrangements, tax base determination usually rests with the higher-level government, with lower levels of government levying supplementary rates on the same base. Tax collection is by one level of government, generally the central government in market economies and the local government in transition economies with proceeds shared downward or upward depending upon revenue yields. Only a handful of developing and transition economies have adopted tax base sharing. A sub-national surcharge on the personal income tax is permitted in Brazil and Croatia. Russia allows a surcharge on corporate income tax. Provincial governments in Pakistan allow local governments to have a supplementary rate on property transfer taxes. While the practice of tax base sharing is uncommon, sharing the proceeds of various taxes on a tax-by-tax basis is frequently practiced in DTEs. Shared taxes are more akin to transfers than autonomous local government revenue since local governments have no say over neither the base nor rate of the tax. In transition economies, in 1999, $49.3 \%$ of sub-national government revenues were obtained 
from shared taxes (see World Bank, 2001). In developing countries, the role of shared taxes in financing sub-national governments is of lesser significance as general revenue sharing is widely practiced.

While giving local authorities some tax authority in principle should increase accountability of local officials to the electorate, giving local governments too much leeway can also present problems, especially when the central government reserves for itself all of the productive taxes. For instance, one local council in Tanzania set up 60 "nuisance" taxes and fees that serve little more than to make the system non-transparent (see Brosio, 2000). Nuisance taxes have also been implemented in some parts of Indonesia, but the central government is trying to limit this distortionary trend by canceling such local government regulations implementing them.

(b) Expenditure Responsibility and Autonomy

Expenditure assignments in DTEs have undergone significant changes in the past two decades. In transition economies such changes reflected a new role for the public sector in support of a market economy. As a consequence sub-national expenditures contracted as a percent of GDP among the transition countries from about $17.2 \%$ in 1980 to $10.8 \%$ in 1999 . Sub-national expenditures in transition economies as a proportion of total public sector expenditures experienced even a sharper decline during the same period from $44.9 \%$ to $22.3 \%$. In developing countries, on the other hand, there has been a gradual, generally piecemeal yet persistent decentralization of expenditure responsibilities. Sub-national expenditures in developing countries as a percent of GDP rose from 3\% of GDP in 1980 to $6.1 \%$ of GDP in 1997. Sub-national expenditures as a percent of total public sector expenditures increased from $12.7 \%$ of total expenditures in 1980 to about $19.6 \%$ of total in 1998 . Sub-national government role in education and health spending show divergent trends in transition economies and developing countries. In transition economies, sub-national educational expenditures as a percent of public sector education expenditures have declined from $71 \%$ in 1981 to $55 \%$ in 2000 . In developing countries, on the other hand, such expenditures have risen from $21 \%$ of total 
public sector education expenditures in 1980 to $40 \%$ of the same in 2000 . In health, the role of sub-national governments in total public sector health expenditures in transition economies declined from about $92 \%$ in 1977 to $39.2 \%$ in 2000. In developing countries, the same role expanded from about $22 \%$ of total education expenditures to $57 \%$ of the same in 1999.

These trends, however, hide the wide variations in such ratios across countries. On the high side, in China (56\%), India (46\%) and Argentina (40\%) are noteworthy for the relative importance of sub-national expenditures in total public expenditures. Moldova (18\%) and South Africa (18\%) have the highest percentage of these expenditures with respect to their GDP. Slovak Republic (8\%), Dominican Republic $(2.6 \%)$ are noted for the lowest share of sub-national expenditures in total public sector expenditures in transition and developing countries respectively. As a percentage of GDP, Croatia (0.01\%), Dominican Republic (0.4\%), Costa Rica and Bahrain (less than $1 \%$ of GDP) are noteworthy.

Many central governments play a larger direct role in service provision than the theory would recommend. For example, in India, South Africa and Mexico, the central government accounts for more than two-thirds of total expenditures. Even in countries where the de jure assignment of expenditures agrees with theoretical principles, practices can differ. Brazil and Pakistan are the cases in point. In Brazil, the central government has found it difficult to withdraw from some purely local functions such as public markets, local schools, and local bridges more than a decade after the adoption of the 1988 constitution. In Pakistan, central and provincial governments have a prominent role in local functions. In Mexico, dominance of the central government results from both the direct assignment of functions to the federal level and the supposed inability of lowerlevel governments to assume delegated responsibilities. In China, Russia and other transition economies, state enterprises continue to have a role in local government functions. Their redistributive role associated with consumer and producer subsidies especially in the housing market is large and threatens the fiscal health of local governments. 
Quite a large number of central governments are involved in local functions. Out of a sample of 33 countries for which details on the assignment of local functions are available, primary education is the sole responsibility of the center in 12 countries and in additional 9 countries central government is involved in this service along with local governments (see Table 2 for details on central government involvement in local functions).

\begin{tabular}{|c|c|c|c|c|c|}
\hline & Service & Number of Co & untries & & \\
\hline & Public Service & $\begin{array}{l}\text { Purely Central } \\
\text { Function }\end{array}$ & $\begin{array}{c}\text { Central } \\
\text { Government } \\
\text { Involvement } \\
\text { (Other) }\end{array}$ & $\begin{array}{l}\text { Purely Local } \\
\text { Function }\end{array}$ & Sample Size \\
\hline \multirow[t]{4}{*}{ Social Services } & $\begin{array}{l}\text { Primary and Preschoo } \\
\text { Education }\end{array}$ & 12 & 9 & 12 & 33 \\
\hline & Secondary Education & 13 & 8 & 10 & 31 \\
\hline & Public Health & 9 & 14 & 8 & 31 \\
\hline & Hospitals & 11 & 12 & 4 & 27 \\
\hline \multirow[t]{2}{*}{ Transportation } & Urban Highways & 7 & 5 & 17 & 29 \\
\hline & Urban Transportation & 6 & 4 & 12 & 22 \\
\hline \multirow[t]{3}{*}{ Utility Services } & $\begin{array}{l}\text { Drinking Water anc } \\
\text { Sewerage }\end{array}$ & 8 & 16 & 6 & 30 \\
\hline & Waste Collection & 0 & 2 & 27 & 29 \\
\hline & Electric Power Supply & 8 & 13 & 4 & 25 \\
\hline \multirow[t]{3}{*}{ Other Services } & Fire Protection & 0 & 5 & 4 & 9 \\
\hline & Public Order and Safety & 1 & 1 & 0 & 2 \\
\hline & Police & 14 & 10 & 5 & 29 \\
\hline
\end{tabular}

Table 2: Central Involvement in Local Functions Remains Extensive Source: Authors' calculations based upon data from World Bank Decentralization Net website

In areas of shared responsibility such as education, health and social services, policies of various levels of government are typically uncoordinated. While social services expenditures tend to be less important in developing countries than industrial countries, the role of the local government in these functions is more important in the latter. These are also the functions that are in some countries mandated by the constitution to be provided universally and free. In transition economies the central 
governments have often attempted to shift social expenditures downward to regional and local governments without providing additional finances. In Bolivia and Venezuela as well, increased sub-national expenditure responsibilities were not matched by equivalent increases in revenue. These largely unfunded mandates have therefore been seen as attempts by national governments to shift deficits downward, creating disharmony and conflicts among governments at different levels. The division of expenditure responsibilities within nations has been further complicated by the role of external donors. External donors in their attempt to create "islands of integrity" associated with the use of their funds have often supported creation of parallel structures of decision making that bypass local government institutions.

Finally, expenditure autonomy (percentage of own expenditure under effective control of sub-national governments) is on average higher ( $74 \%$ on average but $96 \%$ in Croatia, and 7\% in Albania) in transition economies than developing countries (58\% on average but 95\% for Dominican Republic and 23\% for South Africa).

\section{(c) Fiscal Transfers: A Mixed Bag}

Intergovernmental transfers are the dominant source of revenues for sub-national governments in most DTEs. In 1999, they constituted on average $24 \%$ of total revenues for transition economies (93\% in Albania and 4\% in Croatia) and 42\% (81\% in South Africa, $75 \%$ in Peru and 7\% in China) of the same (in 1997) for developing countries. ${ }^{7}$ This ratio ranges from $4 \%$ to $95 \%$ for individual countries. The transfers constituted 75 95\% of sub-national revenues in Indonesia, Nigeria, Mexico, Pakistan and South Africa. The design of these transfers is of critical importance for efficiency and equity of local service provision, autonomy, and fiscal health of sub-national governments (see Shah, 1994, 1998 for general principles and better practices in grant design). To enhance accountability it is desirable to match revenue means (the ability to raise revenues from own sources) as closely as possible with expenditure needs at all levels of government. However, higher level governments must be allowed greater access to revenues than

\footnotetext{
${ }^{7}$ Outliers to the averages for transition and developing countries are listed in parentheses.
} 
needed to fulfill own direct service responsibilities so that they are able to use their spending power through fiscal transfers to fulfill national and regional efficiency and equity objectives. We can identify six broad objectives for national fiscal transfers, each of which suggests a specific design of such transfers (see also Table 3). In the following, we examine adherence to these principles in practice in DTEs.

Table 3: Ensuring Consistency of Grant Design to Achieve Grantor's Objectives

\begin{tabular}{|c|c|c|c|}
\hline Objective & Grant Design & Better Practices & Practices to Avoid \\
\hline Fiscal Gap & $\begin{array}{l}\text { Reassign, tax base } \\
\text { sharing }\end{array}$ & Canada & $\begin{array}{l}\text { Deficit grants, tax } \\
\text { by tax sharing }\end{array}$ \\
\hline Regional disparities & $\begin{array}{l}\text { Fiscal capacity } \\
\text { equalization }\end{array}$ & $\begin{array}{l}\text { Australia, Canada, } \\
\text { Germany, ECA } \\
\text { region }\end{array}$ & $\begin{array}{l}\text { General revenue } \\
\text { sharing }\end{array}$ \\
\hline $\begin{array}{l}\text { Setting national } \\
\text { minimum standard }\end{array}$ & $\begin{array}{l}\text { Block transfers, } \\
\text { conditions on } \\
\text { service standards }\end{array}$ & $\begin{array}{l}\text { Ex-Indonesia roads } \\
\text { and education, Chile } \\
\text { education }\end{array}$ & $\begin{array}{l}\text { Conditions on } \\
\text { spending }\end{array}$ \\
\hline Benefit spillovers & Matching grant & $\begin{array}{l}\text { S. Africa teaching } \\
\text { hospitals transfer }\end{array}$ & \\
\hline $\begin{array}{l}\text { Influencing local } \\
\text { priorities }\end{array}$ & $\begin{array}{l}\text { Open-ended } \\
\text { matching }\end{array}$ & $\begin{array}{l}\text { Canada social } \\
\text { assistance }\end{array}$ & Ad hoc grants \\
\hline Stabilization & $\begin{array}{l}\text { Capital with upkeep } \\
\text { requirement }\end{array}$ & $\begin{array}{l}\text { Political and policy } \\
\text { risk guarantee }\end{array}$ & $\begin{array}{l}\text { Stabilization } \\
\text { without upkeep }\end{array}$ \\
\hline
\end{tabular}

i. Deficit grants to bridge fiscal gaps are still commonplace. The theory suggests tax decentralization or tax base sharing as preferred alternatives to deal with fiscal gaps. In DTEs on the contrary, general revenue sharing or tax-by-tax sharing is typically used to deal with fiscal gaps. A number of countries including China, India, Malaysia, Pakistan, and South Africa have in the past tried deficit grants to fill fiscal gaps at sub-national levels with unwelcome results in terms of mushrooming sub-national deficits. These grants are still in vogue in Bosnia-Herzegovina and Republic Srpska, China, Georgia, Hungary, Moldova, Serbia and Montenegro and South Africa. In Bulgaria, even though there is a 
formula for transferring resources, the system is undermined because of unplanned, end of the year transfers to cover deficits.

ii. Fiscal equalization transfers to correct fiscal inequities and fiscal inefficiencies arising from differentials in regional fiscal capacities have been adopted in a number of Eastern European countries but remain largely untried in developing countries. Most transition economies have equalization components in their grant programs to sub-national governments. Latvia, Lithuania, Poland, Romania, Russia and Ukraine have adopted transfer formulae that explicitly incorporate either fiscal capacity and/or expenditure need equalization concerns. In developing countries, programs using an explicit standard of equalization are untried, although equalization objectives are implicitly attempted in the general revenue sharing mechanisms used in Argentina, Brazil, Colombia, India, Nigeria, Mexico, Pakistan and South Africa. These mechanisms typically combine diverse and conflicting objectives into the same formula and fall significantly short on individual objectives. Because the formulae lack explicit equalization standards, they fail to address regional equity objectives satisfactorily.

iii. Open ended matching grants with the matching rate determined by benefit to compensate for benefit spillovers are not practiced. Although benefit-cost spill-out is a serious factor in a number of countries, such transfers have not been implemented in developing countries with the single exception of South Africa. South Africa provides a closed-ended matching grant to teaching hospitals based upon an estimate of benefit spillovers associated with enrollment of non-local students and use of hospital facilities by non-residents.

iv. Conditional non-matching transfers to set national minimum standards to preserve an internal common market and attain national equity objectives are rarely used. Conditional non-matching transfers to ensure national minimum standards are rarely used in DTEs. Central government transfers to provincial and local governments in Indonesia until 1999, central per capita transfers for education in Chile, Colombia and South Africa, and the capitation grant to Malaysian states come close to the concept of such a transfer. 
v. Matching transfers to influence local priorities in areas of high national but low local priority are practiced in a handful of countries. India, Malaysia, and Pakistan use conditional closed-ended matching programs. Pakistan in late 1990s got into serious difficulty by offering open-ended matching transfers for provincial tax effort. The central government had to abandon this program mid-stream, as it could not meet its obligations under the program.

vi. Capital grants to create macroeconomic stability in depressed regions are commonplace. Capital grants are pervasive in DTEs and most countries have complex processes for initiation and approval of submissions for financing capital projects. These processes are greatly susceptible to lobbying, political pressures and grantmanship and favor projects that give the central government greater visibility. The projects typically lack citizen and stakeholder participation and often fail due to lack of proper local ownership, interest and oversight. The requirement for matching funds helps in monitoring and evaluation of projects and in building local ownership.

vi. Formula based transfers to municipal-local governments are in vogue in Eastern Europe and Latin America but are less commonly practiced in other regions. General purpose transfers to local governments require special considerations as local governments vary in population, size, area served and the type of services offered (for example urban vs. rural). In view of this, it would be advisable to classify local governments by population size, municipality type, and urban/rural distinction and have a separate formula for each class of municipalities. Some common useful components in these formulae are: equal per municipality component, equal per capita component, service area component and fiscal capacity component. The grant funds should vary directly with service area but inversely with fiscal capacity. Even in countries that have instituted such formula based transfer, further design improvements are possible to incorporate considerations listed above.

(d) Borrowing Privileges 
In developing countries, undeveloped markets for long term credit and weak municipal creditworthiness limit municipal access to credit. Nevertheless, the predominant central government policy emphasis is on central controls and consequently less attention has been paid to assistance for borrowing. Argentina, Bolivia, Brazil, Chile and Colombia have cooperative controls on domestic borrowing and administrative controls on foreign borrowing. Ethiopia, India, Indonesia, Korea, Mexico and Peru have administrative controls on domestic borrowing. India, Indonesia, Korea and Peru also have also administrative controls on foreign borrowing. Foreign borrowing is prohibited in Thailand, Pakistan, Armenia, Czech Republic, Kazakhstan, Kyrgyz Republic, Lithuania, Poland, Russia and Slovenia. Domestic borrowing is prohibited in Ethiopia, Mexico, and Thailand (see World Bank, 2000 and World Bank, 2001). Almost all DTEs with the exception of South Africa and Hungary do not have a regulatory framework for declaring local government bankruptcy. In a few countries credit market assistance is available through specialized institutions and central guarantees to jump start municipal access to credit. The menu of choices available to local governments for financing capital projects is quite limited and available alternatives are not conducive to developing a sustainable institutional environment for such finance. This is because macroeconomic instability and lack of fiscal discipline and appropriate regulatory regimes have impeded the development of financial and capital markets. In addition, revenue capacity at the local level is limited due to tax centralization. A first transitory step to provide limited credit market access to local governments may be to establish municipal finance corporations run on commercial principles and to encourage the development of municipal rating agencies to assist in such borrowing. Tax decentralization is also important to establish private sector confidence in lending to local governments and sharing in the risks and rewards of such lending.

\section{How Do We Get There? Revisiting Major Controversies on the Process of Decentralization.}

Most of the decentralization literature (see Shah, 1988, 1994 for surveys of this literature) deals with normative issues regarding the assignment of responsibilities among 
different levels of government and the design of fiscal transfers. The process of decentralization has not received the attention it deserves as the best laid plans can go awry due to implementation difficulties. In this section, we revisit major issues and controversies regarding preferred approaches to obtaining a successful outcome. Key approaches examined are big push versus small steps; bottom up vs. top down; and uniform vs. asymmetric decentralization. In addressing these approaches, the role of inadequate capacity as a constraint to development is also examined.

\section{Big Bang vs. Gradualism}

The literature on federalism calls for a holistic approach to division of powers within nations. This entails an integrated approach to decentralization so that major decisions on political, administrative and fiscal decentralization are adopted as a single package. (Note that crystallization of such an approach may entail a long drawn out process of democratic consultations and consensus building at the grassroots levels.) Such a package of reforms when implemented in a single initiative and implemented over a relatively short period of time would constitute a "big bang" approach to decentralization. A big bang approach has two defining characteristics; (a) it is holistic (comprehensive) and; (b) it is implemented at lightening speed. Such an approach has a number of meritorious elements. The holistic approach ensures that all pieces of the puzzle fit together-i.e. the desired balance in autonomy and accountability is achieved while providing incentives for cost efficiency. This balance might not be achieved under piecemeal reform. For example, if expenditure decentralization is not accompanied by revenue decentralization, the decentralization plan may fail to fully take into account local governments' fiscal capacity and fiscal needs, the availability of good sources of local revenue, the trade-off between equity and efficiency, and the inefficiencies caused by high vertical imbalances (that lead to a lack of incentive for revenue effort and reduced accountability). If political decentralization occurs without fiscal decentralization, people may quickly become disenchanted with decentralization in general because there are no tangible benefits from the reform. Rarely is there some 
unique moment in the political history of a nation that permits such systemic reforms to be feasible. A lightening speed represents the best use of this window of opportunity. This is because all such reforms create winners and losers, and it is generally the central government, which stands to lose power from decentralization that must implement it. Decentralization reforms empower people and local politicians at the expense of national politicians and bureaucrats. If the reforms are planned to take place over a longer period of time, the latter may be given an opportunity to organize, and they are likely to build coalitions to circumvent reforms.

In contrast to the big bang approach, a gradualist approach calls for a sequenced approach to implementing in small steps what may quite possibly be a comprehensive agenda of reform. A gradual approach to decentralization might work if there is likely to be a strong political commitment to reform in the foreseeable future and it is unlikely that groups adversely affected could get organized to block reform.

A gradual approach is sometimes advocated on the grounds that local governments have inadequate capacities to handle newly assigned responsibilities as in Indonesia, Pakistan, Uganda and Vietnam (see Brodjonegoro and Asanuma, 2000 for Indonesia) or citizen participation in local government is weak due to a lack of interest and/or lack of education as in Bangladesh. Gradualism is also advocated when decentralization, if done incorrectly, could cause serious problems. Advocates for gradualism might say this is the case when i) local participation is weak and the local government is captured by the elite, or ii) service delivery and/or revenue collection break down because of weak local government capacity. Lack of capacity at the local level is often offered as a reason why decentralization should proceed slowly. But technical capacity can be contracted at first, and eventually be home-grown. What is essential is for the decentralization process to get started and to allow accountability mechanisms to take effect.

Are There Any True “Big Bang” Reformers?

The word "bang" is defined in the Merriam-Webster dictionary as "a loud percussive or explosive noise." While "Big Bang" reforms are defined in this paper as 
comprehensive decentralization reforms that occur over a short time, rapid but incomplete decentralization reforms in some countries, such as Indonesia, Pakistan and Uganda, may qualify as "big bang" approaches in the Merriam-Webster sense since these did cause "explosive" noises. These indeed are major reform efforts but do not qualify to be termed "big bang" based upon the definition adopted in this paper as they are lacking in some important dimensions. For instance, in all three countries, administrative decentralization has not happened and fiscal decentralization, especially tax decentralization, has been woefully inadequate.

\section{Bottom Up vs. Top Down}

A bottom-up process of decentralization entails resident-voters getting organized in Tiebout-type communities and declaring home rule for local public services and asking higher level governments to be supportive of these efforts. ${ }^{8}$ This has been the dominant mode of decentralization in North America and Northern Europe. A top-down process of decentralization, on the other hand, represents a blueprint drawn by national governments to shift some of their responsibilities downwards. This has been the dominant process of decentralization followed in Southern Europe and all developing and transition countries. A top down process is fraught with major difficulties. National government motivations as highlighted in section 2, have often less to do in improving efficiency, equity and accountability of local governance but more to do with short run political and bureaucratic imperatives (see Table 1). In view of these motivations, the decentralization initiatives are usually piecemeal and incomplete and result in either inadequate reform or even deform as various elements of this change work at cross-purposes and defy success in improving public sector performance.

\footnotetext{
${ }^{8}$ According to Tiebout (1956), people consider tax prices and the public services menu offered by various jusidictions in deciding where to live. Thus, voting with feet leads to jurisdiction formations creating a market analog for public service provision.
} 


\section{Uniform versus Asymmetric Decentralization}

Uniform decentralization implies that the legal status of a constituent unit is the sole criterion used for assigning responsibilities. For example while there may be differential assignment of responsibilities between the categories of cities, towns and villages, there will not be any such differentiation within each category (i.e. all cities will be treated equally). Uniform decentralization is desirable when various jurisdictions are relatively homogeneous with respect to their fiscal capacities and there is no special asymmetry of political or ethnic grouping that calls for special recognition. Asymmetric decentralization, on the other hand, means that constituent jurisdictions are allowed differentiated responsibilities due to political, fiscal or technical capacity considerations (see Shah, 1994 for a framework for asymmetric decentralization of local urban public services). Asymmetric decentralization at the regional level is practiced in a few countries such as Belgium, Canada, India, Malaysia (see Watts, 1999), and now Indonesia. Asymmetric decentralization at the local level is more prevalent in practice (de facto) although such policies may not have been specifically prescribed in law (de jure). In any case asymmetric decentralization makes capacity constraints as a hindrance to decentralization largely a non-issue.

\section{Will Decentralization Be Sustained?}

Decentralization initiatives are likely to be sustained if they were implemented after reaching a broad societal consensus. Sustainability potential is much higher for reforms stemming from grassroots support. If, on the other hand, decentralization was motivated by short-term goals, it increases the likelihood that the process will be reversed later on. Also, since decentralization in most countries is a top-down affair rather than the result of grassroots pressure from below, the interests that benefit from decentralization are rarely organized enough to defend it against reversals. Another reason for backtracking on decentralization is the struggle that politicians have with bureaucrats over its implementation. The struggle with bureaucrats over decentralization has taken place in scores of countries, including Bangladesh, India, Kenya, Pakistan, Sudan, Sri Lanka, Morocco, and Tanzania. This, as noted earlier, may have implications 
for the debate on the pace of decentralization. "Big Bang" decentralization might reduce the resistance that the bureaucracy could effectively mount because they do not have time to regroup and fight the changing conditions, as they would be able to do with gradual change. Thus the pace of decentralization may affect the probability that reforms will be sustained.

Decentralization initiatives during their process of implementation may create dysfunctionalities. This may increase the likelihood that reforms are reversed. Developing countries' experiences show that ill-conceived and poorly executed "decentralization" programs can undermine economic reform policies, exacerbate regional inequalities, empower local traditional elites, foster clientelism, and undermine the delivery of public services (see Remmer and Wibbels, 2000). Eaton (2001) notes that in Argentina, President Menem partially reversed the previous decentralization of revenue to bring provincial governors into his fold. In the Philippines, national legislators were averse to decentralization as it lessened their political power and influence. In Pakistan, both the major political parties have distanced themselves from recent decentralization initiatives, since they see these as attempts by the military regime to weaken their political base.

\section{Local Capture}

Another important issue to consider is that of capture of local government by elites. When civic participation in local government is low, there is a greater risk that interest groups and local elites may capture local governments and direct resources toward their own priorities rather than toward improving the provision of local public goods and poverty alleviation. This is particularly a serious problem for rural areas in countries where there are large inequalities in land ownership (e.g. rural Sindh province of Pakistan). High civic participation and contestability in local elections are particularly important in the DTE context since the ability to "vote with one's feet" is limited. However, the degree of local participation is likely to be endogenous in urban areas; as local governments take on larger roles in expenditure and taxing decisions, then the degree of participation in local government affairs should rise commensurately as the 
stakes increase for participation at the local level. In rural areas, without serious land reforms, outlook remains pessimistic for countries with concentrated land ownership.

A similar concern that election reforms in Latin America have attempted to address is the influence of national politics on local elections. When national and subnational elections coincide, there is a greater probability that national politics will influence results of local elections, reducing the accountability of local officials. In Colombia, the Dominican Republic, Ecuador and Venezuela, sub-national elections do not coincide with national elections. In addition, in some DTEs, local elections can only be contested on a non-party basis.

\section{Lessons for the Future of Decentralization in Indonesia}

Indonesia with the passage of Laws 22 and 25 of 1999 took large steps toward political decentralization and expenditure decentralization to municipal-local governments. All municipal-local services and health, education and culture, public works, agricultural development, communications, environment, land management, capital investment, labor, cooperatives, and management of manufacturing and trading activities were devolved to districts, cities, towns and villages. The major functions that have remained with the central government are justice, defense, police, monetary policy, development planning, and finance. All other functions are reserved for the local governments. The provinces have only been given a minor, coordinating role. While expenditures were devolved, Indonesia, following external advice, did not go forward with the assignment of taxes to local levels. There was a major change however, in the orientation of fiscal transfers. The new transfers were to be formula-based and unconditional. Provinces rich in oil and gas resources were given a larger share of revenues from these natural resources. To create capacity commensurate with new local responsibilities, over two million central staff was transferred from the center to local governments. ${ }^{9}$ The program was implemented at a great speed and completed in less than two years. As a result of these changes, local government expenditures rose from 17

\footnotetext{
${ }^{9}$ Law 22 stipulates that sub-national governments have the ability to hire, fire, and train civil servants.
} 
percent in 2000 to 28 percent in 2001. The World Bank was impressed with the speed of implementation and dubbed this program as the "big bang" (see World Bank, 2003).

The program of decentralization implemented by Indonesia is commendable on a number of counts. It chose to decentralize responsibilities from the center to local governments and in the process by-passing the provinces. This move is thoughtful given the fragile nature of the Indonesian union and a potential threat to such union if the provinces become too powerful (see Shah, 1998 for an analysis of this issue). It also sought to enhance political participation and strengthen home rule for local services. It provides resources to match responsibilities in an unconditional manner to promote greater flexibility and autonomy of decision-making at the local level. It tried to redress long-standing grievances of resource rich provinces by giving them a greater access to resource revenues collected by the center from their provinces. It also introduced a formula-based equalization program (see box 1). Indonesian local governments now have the possibility to match local services with local preferences. The program involved big and bold steps executed with lightening speed. The World Bank characterization of the program as the "big bang" is correct in the Merriam-Webster Dictionary sense of being an explosive in nature. The program, however, could not be characterized as such using the definition of "big bang" presented in this paper. This is because the program has important missing links making it difficult for different pieces of the puzzle to fit together.

\section{Missing Links in the Indonesian Decentralization Program}

Important pieces of the puzzle missing from the Indonesian decentralization program implemented so far are as follows:

\section{Bottom-up Accountability:}

The program is solely focused on enhancing local autonomy with almost complete neglect of bottom-up accountability issues. The Indonesian program implemented so far has failed to address accountability of local governments to residentcitizens. This is for several reasons. 
First, lack of any tax decentralization means that local government would have the pleasure to spending money raised by someone else without experiencing the pain associated with raising taxes. This is likely to create incentives for fiscal mismanagement while enlarging the size of public spending. Over-centralization of taxing responsibility has been a major concern in the past (see Shah and others, 1994 and Shah, 1998) as subnational taxes were only a small proportion of total government revenues in the past $(4 \%$ for municipal governments in 1997/98). This concern was not overcome in the recent program. Only $15 \%$ of kotamadya and $5 \%$ of kabupaten funds are derived from ownsource revenue.

\section{Box 1: The New Fiscal Equalization Program in Indonesia (Dana Alokasi Umum or DAU)}

This program was first introduced in 2001 and has the following elements:

Total pool: Twenty-five percent of total national revenues (not including shared taxes) are reserved for transfers to provinces and kabupaten/kota in shares of $10 \%$ and $90 \%$ respectively. The same formula is used for kabupaten as kota, and it is only slightly modified for the provinces. Both the provincial and kabupaten/kota DAUs are further broken down into three components: lump sum, balancing factor (to maintain "hold harmless"), and the formula amount. For the provinces, the shares of each component are $20 \%$ lump sum, $50 \%$ formula, and $30 \%$ balancing factor. For the kabupaten/kota, the shares are $10 \%$ lump sum, $40 \%$ formula, and $50 \%$ balancing factor.

Lump sum: Twenty percent of the provinces' share of the DAU (which is $10 \%$ of the total DAU) is distributed as equal lump sum amounts to each province (by dividing the total lump sum allocation by the number of provinces). Kabupaten/kota receive $10 \%$ of the total kabupaten/kota share of the DAU (which is $90 \%$ of total DAU) as a lump sum distributed in equal amounts to each kabupaten and kotamadya.

The formula amount: In 2002, a formula was used to distribute $50 \%$ of the provincial DAU and $40 \%$ of the kabupaten/kota DAU. The formula amount allocated to each local government depends on that local government's share in the country-wide local government fiscal gap (sum of all local government fiscal gaps). The fiscal gap is the difference between expenditure needs and fiscal capacity. The expenditure needs for each jurisdiction are approximated by multiplying a weighted index of four variables (population, area, cost differences, and poverty) with the average of all jurisdictions' expenditures. In 2001 equal weights were applied, but by 2002 higher weights were applied to population and cost. Fiscal capacity is approximated by adding an estimate of own source revenues to actual shared revenues (shared taxes and a share of natural resource revenue). Own source revenue is the predicted value based on a regression of own source revenue on the services component of regional GDP. The major shared taxes include the property tax, the land transfer fee, and the income tax (the latter is apportioned according to place of work rather than residence.) One should note that the extra funds that Papua and Aceh receive from natural resources is not taken into account in the calculation of their fiscal capacity and the shared natural resource revenues given to all local governments) only receive a weight of $75 \%$ in the fiscal capacity formula.

Balancing factor: The final $30 \%$ of the provincial DAU and $50 \%$ of the kabupaten/kota DAU is distributed as the balancing factor. Each local government's share of the amount allocated to the balancing factor is determined by that government's share of the total local government wage bill. It is intended to function as a "hold harmless" measure, ensuring that no local government receives less than the previous year's transfer payment. This component is due to be phased out of the DAU eventually. 
Local governments are permitted to create new taxes, but they do not have control over good tax bases. Consequently, some distortionary new local taxes have been created. The justification advanced for inaction on tax assignment was grounded in a concern, forcefully put forward by international development finance institutions, that such an assignment would put a strain on central government finances that were already under great stress. Such an argument to the extent that it holds water, suggests that a major program of decentralization is better undertaken when the country does not face any political or economic turbulence. If, however, the government has already embarked on such a course, then it must ensure that finance follows function. There is some empirical evidence to support this view as well. Recent empirical work demonstrates that concurrent decentralization of tax and expenditure responsibilities actually reduces the size of the public sector (see Ehdaie 1994). Tax decentralization is a major issue that remains on the agenda in Indonesia. Government accountability to the people will be incomplete until the politicians making the decisions about expenditures are the same ones who have to justify tax rates to the populace. Good sources of revenue at the local level include property taxes, property transfer taxes, frontage charges, fuel taxes, environmental charges, hotel and entertainment taxes, tax base sharing of the personal income tax and user charges and fees.

Since most of the financing for local governments is now in the form of unconditional transfers from the center, it further weakens bottom-up accountability as funds flow like manna from heaven. ${ }^{10}$ Such finance de-links local governments from their resident-voters and as a result the responsiveness of local governments to citizen voters and concerns for cost-efficiency are no longer assured. Such financing is also shown empirically to lead to a commensurate increase in the size of local public spending (Ehdaie, 1994) due to the "flypaper effect" (that is, grant money seems to stick where it

\footnotetext{
${ }^{10}$ The DAU is supposed to be formula based, but in $2002,60 \%$ of transfers were allocated by lump sum and the "hold harmless" which provided that sub-national governments should receive no less in transfers than the previous year. The Dana Khusus (DAK), a system of conditional grants, has not yet been implemented. Reports for the Consultative Group on Indonesia (June 2002) suggest that there will be conditional grants for education, basic health, and infrastructure in the 2003 budget, but their design was not available at the writing of this paper.
} 
first lands) but without any observable increase in the quality, quantity and responsiveness of public services.

In the absence of administrative decentralization, moral hazard and bureaucratic incentives to re-centralize have not been overcome. Industrial country experiences suggest that "citizen voice and exit" and local autonomy go hand-in-hand for the success of decentralization policies. In Indonesia, local government regulations are subject to review by the central government and the central government still sets the minimum salaries for civil servants of sub-national governments.

Expenditure assignment is an issue where confusion remains. In some respects local government responsibilities derive from a "residual list"-certain powers (monetary policy etc.) are reserved for the central government, and all others unspecified powers are the domain of the local governments. On the other hand, a positive list of responsibilities (listed previously) is derived from Law 22 (1999). The law is unclear about which responsibilities are mandatory for the local government to take on, and which ones may be shared (because of capacity or cross-jurisdictional externalities). The result of the unclear demarcation of responsibilities is weakened accountability, as people are unsure which level of government is responsible for what. Asymmetric decentralization (of expenditures, revenues, responsibilities) may be appropriate in Indonesia due to the diversity of the country. Some provinces may have the desire and capability to carry out more functions than others. However, a framework is needed to avoid confusion about the separation between central and local government responsibilities and to maintain clear lines of accountability.

There remain some aspects of the political/electoral system that may compromise accountability. As under the old system, the new election laws have not corrected the over-representation of some electoral districts. In addition, local chief executives are not directly elected, and there is no mechanism for popular recall. Finally, the new amendments to the constitution do not make clear that local governments' democratic structures are protected from central government interference or dismissal. 
Coordination of the decentralization process by the central government has been lacking in some respects. Local governments, awaiting regulations from the central government that were never delivered, have proceeded with decentralization even without the guidelines. The result has been local government actions that conflict with central government laws.

\section{Accountability for Results}

Ironically, Indonesia abandoned one of the better-designed performance oriented fiscal transfer programs (Instruksi Presiden, or INPRES education, health and road transfers), which had helped it achieve national minimum service standards across the country. The primary school grant, initiated in 1973/74, provided funds to local governments based on the number of children age 7-12. An additional capital grant was provided to achieve uniform minimum standards of access to education across the country. The health grant implemented in 1974/75 provided local governments with funds based on a formula including medicine needs and requirements for health centers (1 per 30,000 population) but left the decisions on execution to the local governments. Likewise, the district/town road improvement grant allocated funds since 1979/80 to local governments based on such factors as road length, condition, density, and cost. Indonesia would be well advised to reconsider such grants to establish national minimum standards. Such grants can also be used to provide incentives for competitive service delivery by public and private sectors as shown in Box 2. ${ }^{11}$.

\footnotetext{
${ }^{11}$ Note that the new system of transfers is supposed to include the DAK, a conditional transfer. However, its implementation has been limited to reforestation activities.
} 


\section{Box 2: An Example of a Performance Oriented Grant: Education grant to set minimum standards while encouraging competition and innovation}

Allocation basis among local governments: school age population.

Distribution to providers: equal per pupil to both government and private schools.

Conditions: universal access to primary and secondary education regardless of parents' income; improvements in achievement scores; no condition on the use of grant funds.

Penalties for non-compliance with standards: public censure, reduction of grant funds.

Incentives for cost efficiency: retention of savings.

Source: Shah (1998)

It is interesting to note that a number of local governments have recently adopted the criteria of financing schools based upon school enrollments as opposed to the centrally suggested criteria of equal fixed amount per school (see Hofman and Kaiser, 2002, p.6). Recognizing the importance of such transfers, the Government of Indonesia in June 2002 announced plans for the introduction of DAK transfers for basic education, basic health services, and basic infrastructure in the 2003 budget. The design of such transfers had not been worked out at the time this paper was written.

\section{Fiscal Equalization}

Fiscal equalization is an important goal of the new fiscal transfer system, and to this end, an equalization program, the so-called Dana Alokasi Umum (DAU), has been proposed. Under the new system, the equalization transfer is to be determined by a formula that calculates the fiscal gap between the expenditure needs of a local government (based on population, area, costs, and poverty) and its fiscal capacity (based on estimates of own and shared revenues) (see Box 1 for details).

The new equalization program has several meritorious elements. It provides significant resources to local governments in a transparent and somewhat equitable manner. It embodies a well thought out transition for the implementation of such a program through a "hold harmless" provision (guaranteeing no less than the previous year's level of transfer payment) during 2001 and 2002. This provision will provide a smooth transition to the phasing in of the new system over the next 3 to 5 years. 
The program as currently implemented has a number of design flaws. First the total pool of resources is arbitrarily set and is not determined by the application of the equalization formula. This arbitrary determination of pool may be contributing to a negative fiscal balance for the central government after the transfers are accounted for. Fiscal capacity determination is based upon revenue collections as opposed to more desirable alternative of taking into account revenue bases. Expenditure need determination uses adjustment of local expenditures by an index that uses arbitrary weights for population, area, poverty gap and cost factors. The balancing factor is the most indefensible element of the new equalization program as it is based on personnel expenditures. A simpler application of "hold harmless" provision based on total amount of transfers received in the pre-reform year to serve as the minimum grant would have served as a simpler and justifiable alternative. The program also uses the same formula for different categories of local governments and as a result may be contributing to fiscal inequity across different types of local governments. A provision of government regulation PP 84/2001 requiring quarterly reports on the use of DAU funds negates the autonomy objectives of this formula based equalization program. Overall the program does not use an explicit standard of equalization and as a result its accomplishments could not be assessed against a common yardstick. A simpler fiscal capacity equalization program using a national average standard, separately for each type of local governments (kota, kabupaten and the provinces) would have been more desirable. In short, the current equalization program requires a re-examination to make its design consistent with its objectives.

\section{Bureaucratic Culture and Incentives}

In Indonesia, in the past, centralization of responsibility and concentration of controls in bureaucracy created a culture of rent seeking and command and control with little concern for citizens' preferences and needs. Particularly in Indonesia, power has been firmly in the hands of the bureaucracy since the 1970s. 
In Indonesia, operational capacity of the bureaucracy for local governance is deficient. This deficiency, however, can be overcome in the short run by borrowing such capacities from the national governments, from other local governments, from the private sector, and from civil society. In the long run, training of staff and creating an enabling environment for competitive service delivery through partnership with the private sector and civil society can augment operational capacity. A matter of greater concern in Indonesia is that the available capacity is not geared towards serving the citizen-voters. A similar rent seeking bureaucratic culture prevailed in industrial countries not long ago. Over the years, however, industrial countries have shown a remarkable change in the performance of their public sectors. It is interesting to note that this change was brought about not through a system of hierarchical controls, as continue to be the focus in Indonesia but more through strengthened accountability to citizens at large.

Overall the emphasis of these systems of accountability has been to bring about a change in both the bureaucratic culture and the incentives public employees face. This is done by steering attention away from internal bureaucratic processes and input controls to accountability for results. While various countries have followed diverse policies to achieve this transformation, the underlying framework driving these reforms is uniform and firmly grounded in the results oriented management and evaluation framework (ROME). Under ROME, a results based chain provides a yardstick for measuring public sector performance.

\section{Results Oriented Management and Evaluation (ROME) Chain:}

Program/project $=>$ inputs $=>$ activities $=>$ outputs $=>$ reach (stakeholders positively or adversely affected) $=>$ outcome (purpose) $=>$ impact (goal) $=>$ citizen feedback and evaluations $=>$ program design $=>$ program $/$ project

Most ROME related approaches have the following common elements: government as a purchaser but necessarily as a provider of public services; (b) incentives for competitive service delivery; (c) contracts/work programs based upon pre-specified 
output and performance targets and budgetary allocations; (d) managerial flexibility but accountability for results; (e) subsidiarity principle; (f) incentives for cost efficiency and (g) citizen charter, bottom-up accountability.

ROME provides a coherent framework for strategic planning and management based upon learning and accountability in a decentralized environment. This framework calls for competitive wages and task specialization and lack of formal tenures for public personnel. Public providers are given the freedom to succeed or fail. Instead public employees hold the jobs so long as they are able to fulfill the terms of their contracts. Persistent failures initiate the exit process. Responsiveness to citizenry and accountability for results are the cornerstone of this approach (see Box 3). A recent empirical study by Gurgur and Shah (2002) supports this view as it shows that political and bureaucratic culture and centralization of authority represent the most significant determinants of corruption in a sample of 30 countries. In view of this evidence, the ROME framework offers a great potential in Indonesia to improve public sector governance by nurturing responsive and accountable governance. Administrative decentralization is a pre-requisite for implementation of ROME. Administrative decentralization as discussed earlier requires lack of any ex ante controls over the decision by local governments to hire, fire and set terms of employment of local staff. To improve tax collection or the delivery of local public services, local government should have the freedom to contract own taxing and spending responsibilities. Furthermore, local governments should have the authority to pass bylaws in their spheres of responsibility without having to obtain prior clearance from the higher-level government. Local governments in Indonesia do not as yet in practice have the authority to hire and fire senior local staff. The lack of such autonomy is considered the Achilles' heel of the devolution, as the centrally transferred civil servants have no personal stake in the success of the devolution. 


\section{Box 3: Making the Dog Wag Its Tail: Accountability for Results}

\begin{tabular}{|l|l|}
\multicolumn{1}{|c|}{ Old System: vs. "Accountability for Results": } \\
\hline Rigid rules & Managerial flexibility \\
\hline Input controls & Results matter \\
\hline Top-down accountability & Bottom-up accountability \\
\hline Low wages and high perks & Competitive wages but little else \\
\hline Life-long and rotating appointments & $\begin{array}{l}\text { Stay with-it culture but exit with } \\
\text { persistent failures }\end{array}$ \\
\hline Intolerance for risk/innovation & Freedom to fail/succeed \\
\hline
\end{tabular}

Source: Shah (1999).

\section{Concluding Remarks}

In conclusion, while the Indonesian decentralization program is to be commended for its achievements over a short period of time, its long-term success is not assured as the program has failed to recognize and provide incentives for local governments to be accountable and responsive to their residents. Critical missing links in this regard identified in this paper include: (a) tax decentralization; (b) performance oriented transfers to set national minimum standards; (c) equalization to a standard; (d) administrative decentralization and (e) results-oriented management and evaluation. Unless urgent action is taken to overcome these missing links, the bold Indonesian experiment may not bring the expected results in public sector performance in delivering quality local public services as demanded by its citizens. 


\section{Appendix Table 1: Political Decentralization}

\begin{tabular}{|c|c|c|c|c|c|c|c|c|}
\hline & \begin{tabular}{|c|} 
Constitutional \\
safe-guard \\
against \\
arbitrary \\
dismissal of \\
local gov't \\
\end{tabular} & \begin{tabular}{|c|} 
\\
Popular \\
election of \\
local council \\
members \\
\end{tabular} & $\begin{array}{c}\text { Popular } \\
\text { election of } \\
\text { heads of local } \\
\text { councils }\end{array}$ & \begin{tabular}{|c} 
Degree of \\
popular \\
participation \\
in local \\
elections
\end{tabular} & $\begin{array}{c}\text { Provisions for } \\
\text { popular recall } \\
\text { of local } \\
\text { officials }\end{array}$ & $\begin{array}{c}\text { Contestability } \\
\text { in local } \\
\text { elections }\end{array}$ & $\begin{array}{c}\text { Security of } \\
\text { existence for } \\
\text { local } \\
\text { government }\end{array}$ & $\begin{array}{l}\text { Overall political } \\
\text { decentralization }\end{array}$ \\
\hline \multicolumn{9}{|l|}{ Africa } \\
\hline Burkina Faso & no & Yes & & & & & & \\
\hline Mozambique & no & Yes & & low & & & & \\
\hline Nigeria & yes & Yes & no? & low & $?$ & low & $?$ & low \\
\hline Senegal & & Yes & & low? & & & & \\
\hline South Africa & yes & Yes & no & high & yes & high & yes & high \\
\hline Uganda & yes & yes & yes & $?$ & yes & $?$ & $?$ & \\
\hline \multicolumn{9}{|l|}{$\begin{array}{l}\text { East } \\
\text { Asia/Pacific }\end{array}$} \\
\hline China & no & no & no & low & no & low & no & low \\
\hline Indonesia & unclear & yes & no & medium & no & low & no & medium \\
\hline Philippines & yes & yes & yes & high & yes & medium & no & medium \\
\hline \multicolumn{9}{|l|}{$\begin{array}{l}\text { E. Europe/C. } \\
\text { Asia }\end{array}$} \\
\hline Albania & yes & yes & yes & low & $?$ & low & no & \\
\hline $\begin{array}{l}\text { Bosnia and } \\
\text { Herz }\end{array}$ & yes & yes & yes & high & $?$ & high & no & high \\
\hline Czech Rep. & yes & yes & yes & high & $?$ & high & no & high \\
\hline Georgia & yes & yes & no & low & $?$ & low & yes & low \\
\hline Hungary & & yes & yes & & & & & \\
\hline Kazakhstan & no & yes & no & low & $?$ & low & yes & low \\
\hline Moldova & yes & yes & yes & low & $?$ & low & yes & medium \\
\hline Montenegro & yes & yes & yes & low & $?$ & low & no & medium \\
\hline Poland & yes & yes & yes & medium & yes & medium & yes & high \\
\hline Russia & yes & yes & yes & low & $?$ & $\begin{array}{l}\text { medium/ } \\
\text { high? }\end{array}$ & yes & medium \\
\hline Serbia & yes & yes & yes & low & $?$ & low & no & \\
\hline \multicolumn{9}{|l|}{ Latin America } \\
\hline Argentina & $?$ & yes & yes & medium & yes & high & no & medium \\
\hline Brazil & yes & yes & yes & medium & yes & high & yes & high \\
\hline Mexico & no & yes & yes & medium & yes & high & no & medium \\
\hline \multicolumn{9}{|l|}{$\begin{array}{l}\text { Mid. East/N. } \\
\text { Afr. }\end{array}$} \\
\hline Egypt & no & yes & no & & & low & & low \\
\hline \begin{tabular}{|l|} 
Jordan \\
\end{tabular} & yes & yes & yes & medium & & low/medium & & medium \\
\hline Morocco & yes & yes & no & & & high & & medium \\
\hline \multicolumn{9}{|l|}{\begin{tabular}{|l|} 
S. Asia \\
\end{tabular}} \\
\hline Bangladesh & yes & yes & yes & medium & yes & high & no & medium \\
\hline India & yes & yes & no & medium & yes & yes & yes & high \\
\hline Pakistan & No & yes & no & medium & yes & yes & no & medium \\
\hline
\end{tabular}


Appendix Table 2: Administrative Decentralization

\begin{tabular}{|c|c|c|c|c|}
\hline & $\begin{array}{l}\text { Freedom to hire/fire/set } \\
\text { terms of employment of } \\
\text { local gov't employees }\end{array}$ & $\begin{array}{l}\text { Freedom to contract } \\
\text { out own } \\
\text { responsibilities }\end{array}$ & $\begin{array}{c}\text { Administrative } \\
\text { regulatory authority } \\
\text { (by-laws) }\end{array}$ & $\begin{array}{c}\text { Overall } \\
\text { administrative } \\
\text { decentralization }\end{array}$ \\
\hline \multicolumn{5}{|l|}{ Africa } \\
\hline Burkina Faso & & yes (waste) & & \\
\hline \multicolumn{5}{|l|}{ Mozambique } \\
\hline Nigeria & no & no & yes & low \\
\hline Senegal & & & yes? & \\
\hline South Africa & no & yes & yes & medium \\
\hline Uganda & no & yes & yes & low \\
\hline \multicolumn{5}{|c|}{ East Asia and Pacific } \\
\hline China & no & yes & no & low \\
\hline Indonesia & De jure, yes; de facto, no & $\begin{array}{c}\text { De jure, yes; de facto, } \\
\text { no }\end{array}$ & $\begin{array}{c}\text { Central gov't } \\
\text { approval required }\end{array}$ & low \\
\hline Philippines & \begin{tabular}{|c|} 
no \\
\end{tabular} & \begin{tabular}{|l|} 
no \\
\end{tabular} & yes & low \\
\hline \multicolumn{5}{|c|}{$\begin{array}{l}\text { Eastern Europe and } \\
\text { Central Asia }\end{array}$} \\
\hline Albania & yes & yes & yes & high \\
\hline Bosnia and Herz & yes & yes & yes & high \\
\hline Czech Rep. & yes & yes & yes & high \\
\hline Georgia & yes & yes & yes & high \\
\hline \multicolumn{5}{|l|}{ Hungary } \\
\hline Kazakhstan & yes? & no & no & low \\
\hline Moldova & yes & yes & yes & high \\
\hline \multicolumn{5}{|l|}{ Montenegro } \\
\hline Poland & yes & yes & yes & high \\
\hline Russia & no & yes & $?$ & low \\
\hline Serbia & yes & yes & yes & high \\
\hline \multicolumn{5}{|l|}{ Latin America } \\
\hline \multicolumn{5}{|l|}{ Argentina } \\
\hline Brazil & yes & yes & yes & high \\
\hline Mexico & no & yes & yes & low \\
\hline \multicolumn{5}{|l|}{$\begin{array}{l}\text { Middle East/ N. } \\
\text { Africa }\end{array}$} \\
\hline Egypt & no & & yes & \\
\hline \multicolumn{5}{|l|}{ Jordan } \\
\hline \multicolumn{5}{|l|}{ Morocco } \\
\hline \multicolumn{5}{|l|}{ South Asia } \\
\hline Bangladesh & no & yes & yes & low \\
\hline India & no & yes & yes & low \\
\hline Pakistan & no & yes & yes & low \\
\hline
\end{tabular}




\section{Appendix Table 3: Fiscal Decentralization}

\begin{tabular}{|c|c|c|c|c|c|c|}
\hline & $\begin{array}{l}\text { Rate and base } \\
\text { setting for } \\
\text { local revenues }\end{array}$ & \begin{tabular}{|c|} 
Majority of \\
transfers are \\
formula-based \& \\
unconditional \\
\end{tabular} & $\begin{array}{l}\text { Revenues more } \\
\text { or less match } \\
\text { responsibility }\end{array}$ & $\begin{array}{l}\text { Own revenues } \\
\text { finance majority } \\
\text { of expenditures }\end{array}$ & $\begin{array}{l}\text { Responsibility } \\
\text { and control over } \\
\text { all municipal } \\
\text { services }\end{array}$ & $\begin{array}{l}\text { Responsibility and } \\
\text { control over health, } \\
\text { education, welfare }\end{array}$ \\
\hline \multicolumn{7}{|c|}{ 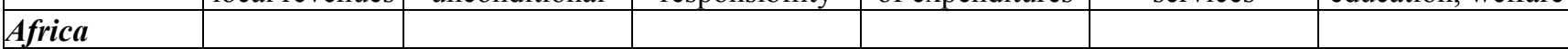 } \\
\hline Burkina Faso & & & no & yes & yes & no \\
\hline Mozambique & & & & yes? & yes & no \\
\hline Nigeria & no & no & no & no & some & no \\
\hline Senegal & & & no & no & yes & yes \\
\hline South Africa & yes & yes & no & yes & yes & no \\
\hline Uganda & yes & yes & no & yes & yes & no \\
\hline \multicolumn{7}{|l|}{$\begin{array}{l}\text { E. } \\
\text { Asia/Pacific }\end{array}$} \\
\hline China & no & yes & yes & no & yes & yes \\
\hline Indonesia & no & yes & $\begin{array}{c}\text { varies by } \\
\text { municipality }\end{array}$ & no & yes & yes \\
\hline Philippines & no & yes & no & no & yes & health and welfare \\
\hline \multicolumn{7}{|l|}{\begin{tabular}{|l} 
E. Eur./C. \\
Asia
\end{tabular}} \\
\hline Albania & rate only & yes & no? & no & yes & yes \\
\hline $\begin{array}{l}\text { Bosnia and } \\
\text { Herz }\end{array}$ & no & no & no? & no & yes & yes \\
\hline Czech Rep. & no & yes & no? & no & yes & yes \\
\hline Georgia & rate & yes & no? & no & yes & yes \\
\hline Hungary & some & no & & no & yes & yes \\
\hline Kazakhstan & no & no & no? & no & yes & yes \\
\hline Moldova & no & no & no? & no & yes & yes \\
\hline Montenegro & rate? & yes? & no? & no & yes & yes \\
\hline Poland & no & yes & yes & yes & yes & yes \\
\hline Russia & no & yes & no & no & yes & yes \\
\hline Serbia & rate only & yes & no & no & yes & yes \\
\hline \multicolumn{7}{|l|}{ L. America } \\
\hline Argentina & yes & yes & yes & yes & yes & no \\
\hline Brazil & yes & yes & yes & yes & yes & yes \\
\hline Mexico & no & yes & yes & no & no & no \\
\hline \multicolumn{7}{|l|}{$\begin{array}{l}\text { Mid East/N } \\
\text { Afr. }\end{array}$} \\
\hline Egypt & no & no & no & no & no & no \\
\hline Jordan & no & no & no & no & yes & no \\
\hline Morocco & no & & & no & yes & \\
\hline \multicolumn{7}{|l|}{ South Asia } \\
\hline Bangladesh & no & yes & yes & yes & yes & no \\
\hline India & no & yes & yes & yes & yes & no \\
\hline Pakistan & no & yes & yes & yes & yes & no \\
\hline
\end{tabular}




\section{Appendix Table 3 (continued): Fiscal Decentralization}

\begin{tabular}{|c|c|c|c|c|c|c|c|}
\hline & $\begin{array}{l}\text { Autonomy for } \\
\text { planning }\end{array}$ & $\begin{array}{c}\text { Autonomy for } \\
\text { procurement }\end{array}$ & $\begin{array}{c}\text { Ability to borrow } \\
\text { from domestic } \\
\text { banks/higher } \\
\text { levels of gov't }\end{array}$ & $\begin{array}{l}\text { Ability to } \\
\text { issues } \\
\text { domestic } \\
\text { bonds } \\
\end{array}$ & $\begin{array}{c}\text { Ability to } \\
\text { borrow from } \\
\text { foreign banks }\end{array}$ & $\begin{array}{c}\text { Ability to } \\
\text { issue foreign } \\
\text { bonds }\end{array}$ & $\begin{array}{c}\text { Overall fiscal } \\
\text { decentralization }\end{array}$ \\
\hline \multicolumn{8}{|l|}{ Africa } \\
\hline Burkina Faso & no & & & & & & \\
\hline \multicolumn{8}{|l|}{ Mozambique } \\
\hline Nigeria & shared & no & no & no & no & no & low \\
\hline \multicolumn{8}{|l|}{ Senegal } \\
\hline South Africa & yes & yes & yes & no & no & no & medium \\
\hline Uganda & yes & $?$ & yes & no & no & no & medium \\
\hline \multicolumn{8}{|c|}{ E. Asia/Pacific } \\
\hline China & no & no & no & no & no & no & low \\
\hline Indonesia & shared & no & yes & yes & $\begin{array}{l}\text { yes, through } \\
\text { central gov't }\end{array}$ & no & medium \\
\hline Philippines & no & no & yes & yes & & & low \\
\hline \multicolumn{8}{|l|}{$\begin{array}{l}\text { E. Eur./C. } \\
\text { Asia }\end{array}$} \\
\hline Albania & yes & no & yes & yes & yes & yes & medium \\
\hline $\begin{array}{l}\text { Bosnia and } \\
\text { Herz }\end{array}$ & yes & no & $\mathrm{y} / \mathrm{n}$ & $\mathrm{y} / \mathrm{n}$ & no & no & \\
\hline Czech Rep. & yes & no & yes & yes & yes & yes & \\
\hline Georgia & yes & no & no & no & no & no & \\
\hline Hungary & & & yes & & yes & & \\
\hline Kazakhstan & yes & no & yes & yes & no & no & modest \\
\hline Moldova & yes & no & no & no & no & no & low \\
\hline Montenegro & yes & no & $?$ & $?$ & $?$ & $?$ & \\
\hline Poland & yes & yes & yes & yes & yes & yes & high \\
\hline Russia & no & no & no & no & no & no & modest \\
\hline Serbia & yes & no & yes & yes & yes & yes & \\
\hline \multicolumn{8}{|l|}{ L. America } \\
\hline Argentina & no & $?$ & yes & yes & yes & yes & medium \\
\hline Brazil & yes & yes & yes & yes & yes & yes & high \\
\hline Mexico & no & no & yes & yes & no & no & low \\
\hline \multicolumn{8}{|l|}{$\begin{array}{l}\text { Mid East/N } \\
\text { Afr. }\end{array}$} \\
\hline Egypt & limited & & yes & & & & low \\
\hline Jordan & & & yes & yes & & & low \\
\hline Morocco & yes & & yes-from gov't & & & & medium \\
\hline \multicolumn{8}{|l|}{ South Asia } \\
\hline Bangladesh & no & no & yes & yes & no & no & medium \\
\hline India & no & no & yes & yes & no & no & medium \\
\hline Pakistan & no & no & yes & yes & no & no & medium \\
\hline
\end{tabular}




\section{References}

Bahl, Roy (1999). “Implementation Rules for Fiscal Decentralization.” Working paper 99-1, International Studies Program, School of Policy Studies, Georgia State University.

Bednar, Jenna (2000). "Formal Theory and Federalism." APSA-CP Newsletter 11(1): 19-23.

Brodjonegoro, Bambang and Shinji Asanuma (2000). "Regional Autonomy and Fiscal Decentralization in Democratic Indonesia." Hitotsubashi Journal of Economics 41 (2): 111-122.

Brosio, Giorgio. "Decentralization in Africa," working paper, October 2000.

Consultative Group on Indonesia - Working Group on Decentralization, "Strengthening Governance and Fighting Corruption in a Decentralized Environment," Working Group on Decentralization Position Paper, June 12, 2002.

Eaton, Kent (2001). "Political Obstacles to Decentralization: Evidence from Argentina and the Philippines." Development and Change 32: 101-127.

Ehdaie, Jaber (1994). "Fiscal Decentralization and the Size of Government: An Extension with Evidence from Cross-Country Data." World Bank Policy Research Working Paper Series No. 1387. Washington, D.C.

Gurgur, Tugrul and Anwar Shah. 2002. "Localization and Corruption: Panacea or Pandora's Box?" in Ehtisham Ahmad and Vito Tanzi (eds.), Managing Fiscal Decentralization, pp. 46-67. London and New York: Routledge Press.

Hofman, Bert and Kai Kaiser, 2002, "The Making of the Big Bang and its Aftermath: A Political Economy Perspective," Paper presented at conference: Can Decentralization Help Re-build Indonesia?, Georgia State University, Atlanta, Georgia, USA, May 2-3, 2002.

Manor, James (1999). The Political Economy of Democratic Decentralization. Washington, D.C.: The World Bank.

Merriam-Webster Online Dictionary, www.m-w.com.

Remmer, Karen and Erik Wibbels (2000). "The Political Economy of Decentralization in Latin America." APSA-CP Newsletter 11(1): 28-31.

Rose-Ackerman, Susan (2000). "The Economics and Politics of Federalism: Tensions and Complementarities." APSA-CP Newsletter 11(1): 16-19. 
Shah, A., Thompson, T. and H. Zou (2004). "The Impact of Decentralisation on Service Delivery, Corruption, Fiscal Management and Growth in Developing and Emerging Market Economies: A Synthesis of Empirical Evidence." CESifo DICE Report Journal for Institutional Comparisons 2(1): 10-14.

Shah, Anwar (2004). "Fiscal Decentralization in Developing and Transition Economies: Progress, Problems and the Promise." World Bank Policy Research Working Paper Series No. 3282. Washington, D.C.

Shah, Anwar (2001). "Inter-jurisdictional Competition and Federal Cooperation. To Compete or to Cooperate? That's not the Question." Presented at the International Forum on Federalism in Mexico: Local and Global Challenges, held in Veracruz, Mexico, 14-17 November, 2001.

Shah, Anwar (1999). "Governing for Results in Globalized and Localized World." The Pakistan Development Review 38:4 Part I, 385-431.

Shah, Anwar (1998). "Balance, Accountability and Responsiveness: Lessons about Decentralization.” World Bank Policy Research Working Paper Series No. 2021. Washington, D.C.

Shah, Anwar (1998). "Indonesia and Pakistan: fiscal decentralization - an elusive goal?” In Richard Bird and Francois Vaillancourt, editors, Fiscal Decentralization in Developing Countries. New York and London: Cambridge University Press.

Shah, Anwar (1994). The Reform of Intergovernmental Fiscal Relations in Developing and Emerging Market Economies. World Bank Policy and Research Series No. 23. Washington, D.C.

Shah, Anwar et al (1994). "Intergovernmental Fiscal Relations in Indonesia.” World Bank Discussion Paper No. 239, Washington, DC: The World Bank.

Shah, Anwar (1988). "Capitalization and the Theory of Local Public Finance: An Interpretive Essay.” Journal of Economic Surveys 2 (3): 209-243.

Tiebout, Charles (1956). "A Pure Theory of Local Expenditures," Journal of Political Economy 64(5): 416-24.

Watts, Ronald L. (1999). Comparing Federal Systems. Second Edition. Montreal and Kingston: McGill - Queen's University Press.

Willis, Garman and Haggard (1999). "The Politics of Decentralization in Latin America." Latin American Research Review, Winter 199934 (1): 7-46.

World Bank (2001). Decentralization in the Transition Economies: Challenges and the Road Ahead. Washington, D.C. 
World Bank (2000). Entering the $21^{\text {st }}$ Century. World Development Report 1999/2000. Oxford University Press.

World Bank (2003). Decentralizing Indonesia: A Regional Public Expenditure Review Overview Report, Washington, D.C.: The World Bank. 